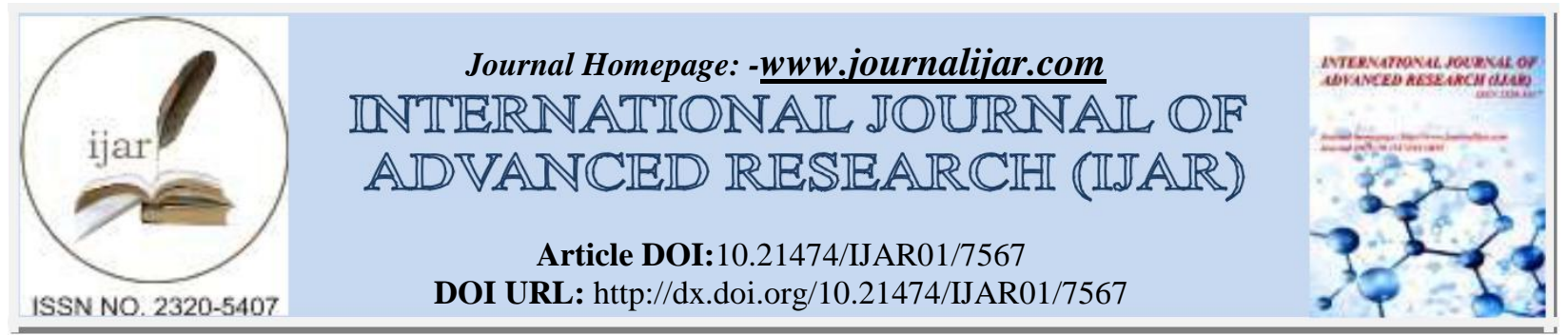

RESEARCH ARTICLE

\title{
STATUS OF COMMERCIAL SHRIMP, FENEROPENEAUS INDICUS (INDIAN PRAWN) FROM PUTHIYAPPA HARBOUR, KOZHIKODE, KERALA WITH RESPECT TO CONSUMER SAFETY.
}

\author{
${ }^{*}$ Rini Joseph ${ }^{1}$, Job Liyo ${ }^{2}$, Deepthi M.P ${ }^{3}$, Jijo George ${ }^{4}$ and Dr. Chitra. G' \\ 1. Department of Zoology, Nirmala College for Women. \\ 2. Department of Life Science, Central University, Tamilnadu. \\ 3. Kongunadu Arts and Science College, Coimbatore. \\ 4. M.S Swaminathan Research Foundation, Wayanad.
}

\section{Manuscript Info}

Manuscript History

Received: 15 June 2018

Final Accepted: 17 July 2018

Published: August 2018

Keywords:-

Fenneropeneaus indicus, Biochemical composition, Microbial quality, Heavy metal contamination analysis.

\section{Abstract}

The Levels of contaminants in fish are of particular interest, because of high potential risks to humans who consumes them. In the present study, commercially important marine Indian prawnFenneropeneaus indicus samples were collected from harbour (Fish Harbour Centre, Puthiyappa , Kozhikode district, Kerala), local market, super market and processing centre (Uniroyal Marine Exports Ltd., Vengalam, Kozikode district, Kerala). Biochemical composition such as protein, carbohydrate, fat, ash, moisture content and calorific contents were determined in the muscle tissues of collected prawn samples. Microbial qualities were analyzed to detect the presence of human pathogenic microbes such as E.coli, Vibrio colerae, Pseudomonas aerugenosa, Staphylococcus aureus and Salmonella shigella. Contamination of heavy metals namely Zinc, Mercury, Lead, Cadmium and Chromium were also evaluated using Atomic Absorption Spectrophotometric method. Maximum Protein content $(24.6 \mathrm{~g} / 100 \mathrm{mg})$ and calorific content (134.521 kcal/gm) observed in supermarket samples when compared to other samples. Fat content $(0.80 \mathrm{~g} / 100 \mathrm{mg})$ was obtained maximum in processing centre samples. The heavy metal contaminants include $\mathrm{Zn}, \mathrm{Hg}, \mathrm{Pb}, \mathrm{Cd}$ and $\mathrm{Cr}$ was below the detectable limit $(0.01 \%)$ in all the samples. The highest total plate count at $37^{0} \mathrm{C}$ was observed in local market and the presence of human pathogenic microbes such as E. coli and Staphylococcus aureus was also noted. Therefore, it can be concluded that Fenneropeneaus indicus (Indian prawn) from harbour, local market, super market and processing center are safe to consume in terms of biochemical, microbial quality and heavy metal concentration and do not constitute a risk for human health.

Copy Right, IJAR, 2018,. All rights reserved.

\section{Introduction:-}

Shrimp is a decapod crustacean, with stalked eyed with extended narrow muscular abdomens, long antennae and slender legs. Shrimp plays a imperative role in the food chain and are important food source from larger animals ranging from fish to whales. The muscular abdomen of many shrimps are edible to humans and are widely caught 
and farmed for human consumption. The growing human population has increased the needs for food supply because they have good protein source (Bannasamyet al, 2009).

The development of fish and fishery products export from Kerala has gone hand in hand with the evolution of the fish processing sector. A distinct feature of the processing sector in Kerala is its dependence on the pre processing sector which is popularly known as peeling shed. The sea food products exported from Kerala is dominated by frozen Shrimp, Squid etc.

Prawns are considered by a variety of health experts to be among the healthiest food in the world, by considering many nutritional benefits. In India, millions of people are malnourished. Protein deficiency may be minimized to some extent by making available cheaper fish meal item which are available to local communities. Prawns are a great source of high quality protein and provide some of the most important vitamins and minerals that make up a healthy diet. They are surprisingly low in calories and are made up of extremely healthy cholesterol. Eating prawns provides a complete protein, which means it includes all 9 essential amino acids in the right proportion for the body to function properly. In fact 100 grams of prawn contains about 25 gram of protein approximately the same as similar amount of chicken or beef.

Prawns are extremely low in calories. The same 100 grams of prawns contains only about 115 calories. While prawns contain higher than average amount of cholesterol, they do not lead to higher cholesterol levels in the body due to their healthy fat profile. This is because they contain almost three times or more omega 3 fatty acids than they do omega 6 fatty acids. These essential fatty acids provide benefits for human e.g., eye(retina) and brain development and function( Conner et al., 1992).Studies have shown that foods with high amounts of omega 3 are associated with reduced risks of heart attacks and lower blood pressure. Shellfishes contain potent source of nutrients for the maintenance and growth of human body (Dong, 2001).

In fact, the cholesterol contained in prawns is vital for healthy diet. Prawns are greatest source of Vitamin B-6, B-12 and Niacin, which help the body to produce energy, built muscles and replenish red blood cells.

Prawns contain significant amount of calcium and iron, Iron is the mineral that is essential for the body for effectively distribute oxygen. And because it is in only a few types of food, Iron deficiency that causes severe exhaustion are surprisingly widespread, especially for women. Prawn helps to built strong bones because they contain phosphorous, magnesium, copper, calcium, iron etc and dietary minerals. Some elements such as copper, zinc, manganese, iron, and chromium are helpful for biological function and if they are found in acceptable levels are very useful for human health (Abdullah et al., 2009).Since, shrimp is one of the most delicious seafood and almost every nation's traditional meal consuming a variety of food in balanced portions will avoid deficiency diseases and chronic death related disorders.

But Pollution is one of the major threats to marine organism. Contamination by heavy metal is one of the real problem which human was exposed, can cause harmful effects on air, water, soil, planet and human health. Industrial waste, chemical structure of land and metal of mining can be considered as source of heavy metal pollution in aquatic environment (Venodeni and Narayanan 2008).

Heavy metals are harmful and insidious pollutants because of their non-biodegradable nature and potential to cause adverse effects human being beyond certain level of exposure and adsorption. Most of industrial waste contain trace elements like $\mathrm{Zn}, \mathrm{Cu}, \mathrm{Pb}$ in have been extremely dangerous to our biota. Toxic chemicals are very harmful even at low concentrations which ingested over a long time period. Heavy metals are those whose density is more than $5 \mathrm{~g}$ /cubic meter. Once heavy metals are ingested, numerous health problems occurs includes learning disabilities, impaired protein and haemoglobin synthesis and shorten the lifespan of red blood cells which leads to severe anaemia in children( Sultana et al., 1998) Under certain environmental conditions these heavy metals may accumulate up to toxic concentration and causes ecological damage (Sivaperumalet al, 2007).

It is rather concern that over $80 \%$ of the industries discharges their solid waste, liquid and gaseous effluents containing toxic concentration of heavy metal such as cadmium, copper, zinc and nickel into the environment without any pre treatment. Such effluents discharged from industries constitutes a number of chemicals such as carbonates, bicarbonates, nitrates, phosphate and toxic metals in addition to the total suspended solid and other 
toxicant when these effluents are discharged into environment. They disrupt the ecological cycle of living organism causing massive destruction of aquatic flora and fauna.

Biological contaminants such as bacteria, viruses, protozoa, helianthus constitute the major cause for food born disease such as Cholera, E.coli gastroenteritis, Salmonellosis, Shigellosis, Typhoid fever, Campylobacteriosis, Brucellosis, Amoebiasis and Poliomyelitis with varying degrees of severity ranging from mild indisposition to Chronic to life threatening illness. Microbial activities accounts for major spoilage in fish (Merlineet al., 2010). Consumption of spoiled fish and fish products results in food poisoning. There are three important aspects in the quality of fish includes nutritional value, safety and sensory characteristics (Ababouch, 2005).

Now days, Food security is a complex issue, where fish and fishery products are generally regarded as high risk commodity in respect to pathogen contents, natural toxins and other possible contaminants and adulterants. The food and agricultural organization of United Nations and the world health organization (FAO/WHO Codex Alimentarus Commission., 2007), states that the illness due to contamination of food is the most widespread problems in the contemporary world and an important cause of reduced economic productivity ( Mozaffarianet al., 2006). According to Higgins, standards of sanitation, method of handling and the time/temperature of holding fish are crucial elements to assure quality. The disease caused by bacterial infection forms the largest economic losses due to health problems and also it imbalances the food web and food chain.

The project aims to determine the microbial quality, heavy metal content and nutritional quality of some commercial important prawn species which is directly collected from the Fish Harbour centre, Puthiyappa, Kozhikode district, Kerala and also samples collected from the distributers, small scale shop keepers from within 12 $\mathrm{km}$ from the fish harbour centre and export quality prawn samples from Uniroyal marine exports ltd., Vengalam, Kozhikode district, Kerala.

\section{Materials and Methods:-}

\section{Study area:-}

The muscle samples of Fenneropenaeus indicus were collected from four different sampling stations, Kozhikode district, Kerala.

1. Fish harbour centre, Puthiyappa - it's an important fishing village of Kozhikode district which is situated to the north of Kozhikode city, $7 \mathrm{~km}$ away at latitude $11^{0} 19^{11} \mathrm{~N}$ and $75^{0} 44^{11} \mathrm{E}$ respectively.

2. Fish vendors of local market within a distance of $12 \mathrm{~km}$ from the harbour.

3. Uniroyal Marine Exports ltd, processing industry receives raw prawn from Peeling shed and stored in ice stock below $4^{0} \mathrm{C}$.

4. Processed and packed samples from super market.

Image.1:-showing Fenneropenaeus indicus

Sample analysis:-

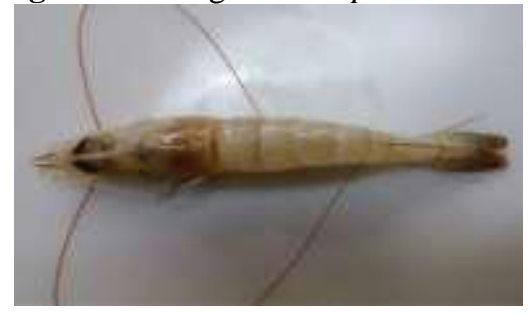

Nutritional Status:-

Nutritional parameters viz Protein, Lipid, Carbohydrate, Ash test were analysed using Bradford method., 1976, Folchet al., 1957, Hedge and Hofreiter., 1962, AOAC., 2009 respectively.

Microbial analysis:-

Microbial quality was estimated by isolation of bacteria, Eschericha coli, Salmonella shigella, Vibrio cholerae, Pseudomonas aeruginosa, Staphylococcs aureus.

\section{Heavy metal analysis:-}

Flame absorption spectrophotometer (AA-0303-0152) with multi elements hollow cathode lamp was used to evaluate the presence of heavy metals viz Cadmium, copper, mercury, zinc and lead in muscle tissues of 
Fenneropenaeus indicus. Air acetylene was used as fuel for flame. The wave length (nm) analysed as follows: $228.0 \mathrm{~nm}$ and $0.7 \mathrm{~nm}$ for $\mathrm{Cd}, 283.3 \mathrm{~nm}$ and $0.7 \mathrm{~nm}$ for $\mathrm{Pb}, 357.9 \mathrm{~nm}$ and $0.07 \mathrm{~nm}$ for $\mathrm{Cr}$, and $253.7 \mathrm{~nm}$ and $0.07 \mathrm{~nm} \mathrm{Hg}$ respectively.

\section{Results and Discussions:-}

\begin{tabular}{|l|l|l|l|l|}
\hline \multicolumn{5}{|c|}{ Biochemical compositions (g) } \\
\hline & Harbour sample & $\begin{array}{l}\text { Local market } \\
\text { sample }\end{array}$ & $\begin{array}{l}\text { Processing centre } \\
\text { Sample }\end{array}$ & $\begin{array}{l}\text { Super market } \\
\text { sample }\end{array}$ \\
\hline Protein & 18.47 & 12.17 & 22.7 & 24.6 \\
\hline Carbohydrate & 6.38 & 5.17 & 1.68 & 6.05 \\
\hline Fat & 0.75 & 0.60 & 0.80 & 0.71 \\
\hline Ash & 1.0 & 0.95 & 1.72 & 1.52 \\
\hline Moisture & $73.4 \%$ & $77.4 \%$ & $73.2 \%$ & $73.2 \%$ \\
\hline
\end{tabular}

\begin{tabular}{|c|c|c|c|c|c|}
\hline \multicolumn{6}{|c|}{ Heavy metal concentration $(\mathrm{mg} / \mathrm{kg})$} \\
\hline & $\begin{array}{l}\text { Harbour } \\
\text { sample }\end{array}$ & $\begin{array}{l}\text { Local market } \\
\text { Sample }\end{array}$ & $\begin{array}{l}\text { Processing centre } \\
\text { sample }\end{array}$ & \begin{tabular}{l|l} 
Super market \\
Sample
\end{tabular} & $\begin{array}{r}\text { FAO/WHO } \\
\text { Permissible limit }\end{array}$ \\
\hline Zinc & & & \multirow{5}{*}{\multicolumn{2}{|c|}{ Below Detectable limit ( DL:0.05 mg $/ \mathrm{kg}$ ) }} & $3-100 \mathrm{mg} / \mathrm{kg}$ \\
\hline Mercury & & & & & $0.5 \mathrm{mg} / \mathrm{kg}$ \\
\hline Lead & & & & & $0.5-6 \mathrm{mg} / \mathrm{kg}$ \\
\hline Cadmium & & & & & $0.05-5.5 \mathrm{mg} / \mathrm{kg}$ \\
\hline Chromium & & & & & $50 \mathrm{mg} / \mathrm{kg}$ \\
\hline \multicolumn{6}{|c|}{ Microbial Quality (cfu/gms) } \\
\hline \multicolumn{2}{|c|}{ Human pathogenic } & $\begin{array}{l}\text { Harbour } \\
\text { Sample }\end{array}$ & \begin{tabular}{l|l}
$\begin{array}{l}\text { Local market } \\
\text { sample }\end{array}$
\end{tabular} & $\begin{array}{l}\text { Processing centre } \\
\text { Sample }\end{array}$ & $\begin{array}{l}\text { Super market } \\
\text { Sample }\end{array}$ \\
\hline \multicolumn{2}{|c|}{ Total plate count at $37^{\circ} \mathrm{C}$} & $0.8 \mathrm{cfu} / \mathrm{gm}$ & $5.7 \mathrm{cfu} / \mathrm{gm}$ & $0.4 \mathrm{cfu} / \mathrm{gm}$ & $0.2 \mathrm{cfu} / \mathrm{gm}$ \\
\hline \multicolumn{2}{|c|}{ Escherichia coli } & Present & Present & - & - \\
\hline \multicolumn{2}{|c|}{ Vibrio cholerae } & - & - & - & - \\
\hline \multicolumn{2}{|c|}{ Pseudomonas aerugenosa } & - & - & - & - \\
\hline \multicolumn{2}{|c|}{ Salmonella shigella } & - & - & - & - \\
\hline \multicolumn{2}{|c|}{ Staphylococcus aureus } & Present & Present & - & - \\
\hline
\end{tabular}

According to Shahina Banu et al., (2016) Penaeid prawns provides good protein source with low fat and higher amount of essential amino acids and all these shrimps are recommended as a healthy and good nutritious food choice for consumption by humans.

The sample gathered from supermarket possess high protein content and approximately comparable level in sample collected from processing centre and harbour. The minimum level of protein content were found to be in the sample collected from local market on account of washing process and improper handling procedure. Ravichandran et al., (2009) pointed out that when moisture content of the sample increases; the protein content will get decreased. The washing process in the local market will increase the moisture content, leads to the aggregation of protein molecule and there by decrease in the protein level of the sample Fenneropenaeus indicus. If the moisture content is maintained low the protein molecule will be in free form, so that no denaturation occurs and that is why sample showed high protein content in processing centre and supermarket. Fenneropenaeus indicus is a good source of protein and metabolic energy and average mineral support.

Carbohydrate content in the sample from supermarket was maintained by appropriate handling and maintenance of proper time and temperature while transporting and processing. Hence, no denaturation occurs. The fat content was observed more in processing centre samples; this may be due to the treatment with sodium tri phosphate (STPP), salt, paparic acid as preservative and colouring agent respectively. The processing centre and supermarket sample contain more amount of ash content. This may be due to the use of chemical preservative while processing the sample.

The total viable colony count indicates the freshness level of the prawn samples. It has been recorded that the increased number of colonies and colony forming units are not safe for consumption. Ariyawanasa et al., (2005) observed a poor correlation obtained between the pathogen and population of indicator organisms such as total 
coliforms, faecal coliforms and E.coli. Among all other samples the local market samples contains more colony forming unit, because of improper handling procedure, water and using equipments such as unhygienic vessels, plat forms, knife used in shops. When microbial content level is more the calorific value will decrease, this is due to degradation of components by microbes. In all samples the microbial quality was below the recommended level of 7 x $10^{5}$ cfu. Ubeyratne et al.,(2008) evaluated the reason for commercial market failure in the industries would improve the seafood distribution with other fresh products in terms of appearance, odour, flavour, texture and thus eliminating food born pathogen and thereby ensuring food safety. The quality of processed products depends on the quality of raw materials and it is difficult to preserve at the time between the harvesting and processing periods. During this period shrimps continue to be deteriorated (Antony et al., 2005) hence, the quality of the shrimp has to be maintained till preservation.

The heavy metal content recorded in muscle tissues samples were below detectable limit or recommended limit $(0.001 \mathrm{mg} / \mathrm{kg})$ of FAO and WHO. Hence, the tissue samples observed was not contaminated with toxic heavy metals.

\section{Conclusion:-}

1. Present investigation proved that Fenneropenaeus indicus available in Puthiyappa harbour, local market, super market and processing centre were in good quality in terms of biochemical and microbial content.

2. Microbial counts were below than the acceptable limit recommended by FAO.

3. Heavy metal accumulation was not detected in the prawn samples.

4. There by Fenneropenaeus indicus collected from the selected localities were safe for human consumption.

\section{Recommendations:-}

1. Landing centre and local markets should maintain hygienically and awareness must be created among those involved in catchment, processing, sale, preservation etc.

2. Govt. should take necessary steps to monitor the levels of industrial and domestic wastes in to water bodies.

3. Coastal environment should be monitored periodically by govt. agencies.

4. Consumers also aware about the quality of sea foods.

\section{References:-}

1. Ababouch, L, (2005) Preservation techniques of fish utilization and marketing services. Food and Agriculture Organization (FAO), A Fisheries Technique Paper.

2. Abdullah, O., Ayse, O., Mevlut, A., Gozde, G. and Jelena, M. (2009) A comparative study on proximate, mineral and fatty acid compositions of deep seawater rose shrimp (Parapenaeuslongirostris, Lucas, 1846) and red shrimp (Plesionikamartia, A.Milne-Edwards, 1883). Journal of Animal and Veterinary Advances. 8(1):183189.

3. Antony, M.M., Jeyasekaran, G., Shakila, R.J. and Shanmugam.(2005) Microbial quality of raw shrimps processed in seafood processing plants of Tuticorin, Tamil Nadu. Asian Fisheries Sciences.15:33-41.

4. Ariyawansa, S.W.S., Hettiarachchi, K.S. and Jayasooria, S.P. (2005) Microbiological quality of fresh and frozen cultured black tiger shrimp cultured in Srilanka. Srilanka Journal of Aquaculture Sciences. 10:73-83.

5. Bahnaswamy, M., Khedr, A and Dheena, N. (2009) Seasonal variations of heavy metals concentrations from Manzala, Egpyt. Journal of applied Sciences Research. 5(7): 845-852.

6. Bradford, M. M. (1976) A rapid and sensitive method for the quantitation of microgram quantities of protein utilizing the principle of protein dye binding. Anal biochem 72:248-254.

7. Conner, W.E., Neuringer, M., Reisbick ,S.(1992) Essential fatty acids: The importance of n-3 fatty acids in the retina and brain. Journal of Nutrition Review. 50: 21-29.

8. Dong, F.M. (2001) The nutritional value of shellfish. A Washington Sea Grant Programme publication, pp: 8.

9. FAO and WHO. (2007) The state of world fisheries and Aquaculture Organization of the United Nations, Rome.162.

10. Floch, J., Lees, M, Stanley, G. H. S. (1957) A simple method for the isolation and purification of total lipids from animal tissues. The Journal of biochemical chemistry. 226: 497- 509.

11. Hedge, J.E. and Hofreiter, B.T. (1962) In: Carbohydrate Chemistry, 17 (Eds. Whistler R.L and Be Miller, J.N. ), Acadamic Press, New York.

12. Merline, X., Chitra, G and Dhanalakshmi, B. (2015) Estimation of amines and amine forming bacteria in edible marine fish Sardinellalongeceps and its products. International Journal of Recent Scientific Research. 6(12): $7936-7940$. 
13. Mozaffarian, D. and Rimm, E.B. (2006) Fish intake contaminants and human health evaluvating the risks and benefits. Journal of Animal Science. 296 (15): 1885-1899.

14. Ravichandran, S., Rameshkumar, G., and Rosario Prince, A. (2009) Biochemical Composition of Shell and Flesh of the Indian White Shrimp Penaeusindicus. American-Eurasian Journal of Scientific Research 4 (3): 191-194, 2009.

15. ShahinaBanu, S.K., Hareesh, K. and SrinivasuluReddy ,M. (2016) Evaluation of Nutritional status of Penaeid Prawns through Proximate Composition Studies. International Journal of Fisheries and Aquatic Studies. 4(1): 13-19.

16. Siveperumal, P., Sankar, T.V. and Viswanathan Nair, P.G. (2007). Heavy metal concentrations in fish,shell fish and fish products from Internal markets of India. International Journal of Food Chemistry. 102:612 -620.

17. Sultha, R and D.P. Rao. (1998) Bioaccumulation patterns of zinc, copper, lead and cadmiumin grey mullet, Mugilcephalus, from harbour waters of Visakhapatnam, India. Bulletin of environmental contamination and toxicology. 60 (6): 949-955.

18. Ubeyratne, K.,RameshBabu,K and M.RatnaRaju. (2008)Proximate composition of the prawn, Macrobrachiumrosenbergiifrom Andhra Pradesh Coast, India. International Journal of aquaculture Sciences. 8: 16-20.

19. Venodhini, R and Narayanam, M. (2008) Bioaccumulation of heavy metals in organs of fresh water fish Cyprinuscarpeo (common carp) and prawns. International Journal Environmental Research and Technology. 5(2): $179-182$. 